\title{
Tribute to Prof. Geoffrey Burnstock: his contribution to acupuncture
}

\author{
Yong Tang ${ }^{1,2,3}$ (D) Peter Illes ${ }^{1,2,4}$ \\ Received: 19 August 2020 / Accepted: 7 September 2020 / Published online: 9 October 2020 \\ (C) The Author(s) 2020
}

Keywords Tribute $\cdot$ Prof. Geoffrey Burnstock $\cdot$ Purinergic signalling

As the creator of purinergic signalling [1], Prof. Geoffrey Burnstock (1929-2020) [2] also made important contributions to the science of acupuncture (AP). AP family procedures include mechanical needling, electroacupuncture, moxibustion, cupping, etc. [3]. His insightful hypothesis on the natural scientific basis of AP in 2009 [4] led to an explosion of research worldwide that aimed to explaining how purinergic signalling contributes to AP. The development of our understanding on AP-induced analgesia has been elaborately documented in the past [5-7]; hence, in this article, we summarize Geoff's distinguished contribution to, and profound impact on, AP and also disclose some personal accounts of his impact on our personal careers in specific, and on the Chinese AP community on a larger scale.

\section{Novel hypothesis on the purinergic mode of action of acupuncture}

AP family procedures, originally developed in China, are widely used in over 183 countries and regions all over the

This article is part of the Topical Collection on A Tribute to Professor Geoff Burnstock.

Yong Tang

tangyong@cdutcm.edu.cn

$\triangle$ Peter Illes

peter.1lles@medizin.uni-leipzig.de

1 International Collaborative Center on Big Science Plan for Purine Signalling, Chengdu University of Traditional Chinese Medicine, Chengdu 610075, China

2 School of Acupuncture and Tuina, Chengdu University of Traditional Chinese Medicine, Chengdu 610075, China

3 Key Laboratory of Sichuan Province for Acupuncture \& Chronobiology, Chengdu 610075, China

4 Rudolf-Boehm-Institut für Pharmakologie und Toxikologie, Universität Leipzig, 04107 Leipzig, Germany world. In 1980, 43 kinds of diseases were recommended by the WHO to be treated by AP, and this number was increased to 64 in 1996. In 1997, an NIH consensus was reached and communicated to the public, stating that AP verifiably works on nausea, vomiting, pain, and other conditions, based on evidence provided by clinical trials and the endorphin theory of its mode of action $[8,9]$. However, the endorphin hypothesis still failed to completely explain how AP acts, and therefore, it was a major development when in 2009 Geoff published his hypothesis [4], later updated in 2011 [10] and 2014 [11]. He proposed that insertion and twisting of the needles employed in AP mechanically deform the skin, causing the local release of ATP by keratinocytes (1) (Fig. 1). The ATP binds to and activates $\mathrm{P} 2 \mathrm{X} 3$ and $\mathrm{P} 2 \mathrm{X} 2 / 3$ receptors located on sensory nerve endings in the skin (2) to initiate action potentials. The signal is then relayed via the dorsal root ganglia to the spinal cord (3) and subsequently through interneuronal pathways (4) to the brain stem (5), which contains motor neurons that control the activity of the gut, lungs, heart, arteries, and reproductive organs - all major targets for AP. Signals also travel to the pain centers of the cortex, delivering a message to inhibit pain (6) [11].

Subsequently, AP research in the field of purinergic signalling started to flourish and a large set of data has been accumulated on changes in purine (ATP, adenosine) concentrations, both locally and in the CNS, induced by manual acupuncture, electroacupuncture, or moxibustion [12-17]. The participation of purinergic receptors (P1: A1, A2a, A2b, A3) [18-34], (P2: P2X2, P2X3, P2X7, P2Y1, P2Y13) [35-52], and neuronal pathways bearing these receptors $[53,54]$ has been confirmed in different AP-sensitive conditions (pain, inflammation, myocardial ischemia, obesity, cerebral ischemia). The functionalized acupuncture needle as a SERS (surfaceenhanced Raman spectroscopy)-active platform was developed for rapid and sensitive determination of ATP concentration [55], and led further support to the purinergic basis of AP.

It is worth pointing out that AP science has enormously benefited from two findings confirming purinergic 


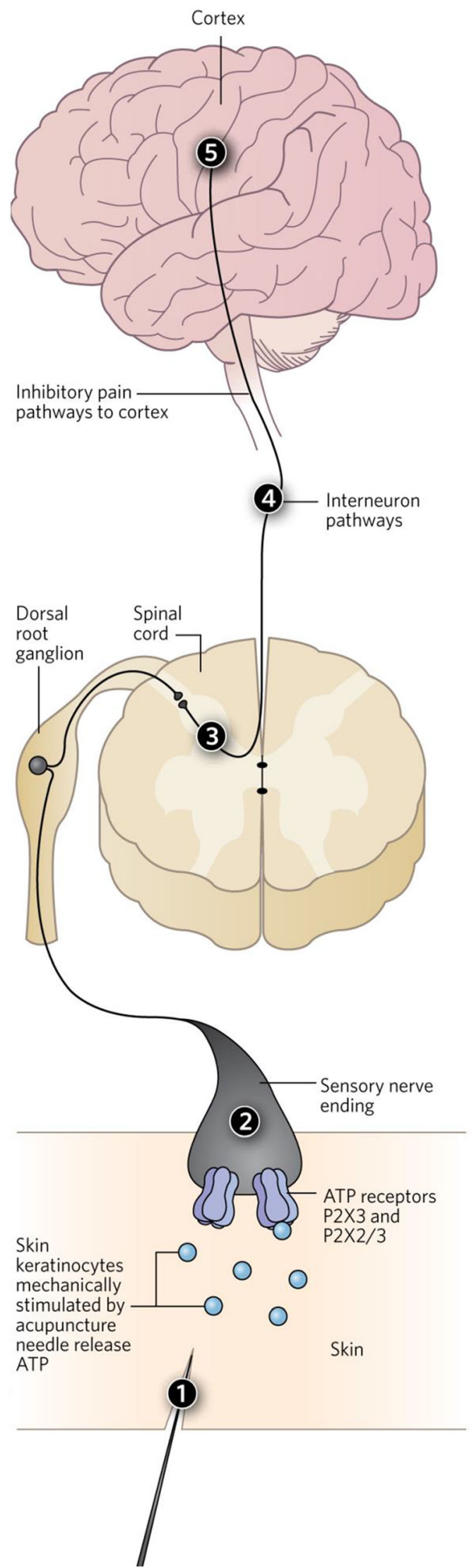

Fig. 1 Purinergic hypothesis on acupuncture mechanism. For explanation, see text mechanisms as participating in AP. The first is the evidence that local adenosine and adenosine A1 receptors mediate the anti-nociceptive effect of acupuncture in mice, as shown by Maiken Nedergaard and her group, which indicated that the needling site at an AP point is crucial to explain the mode of action of AP analgesia. The second was that the injection of prostatic acid phosphatase (PAP) to an AP point slowed down the degradation of adenosine and caused strong analgesia in mice, a procedure named "PAPupuncture" by Mark Zylka in 2012 [56]. Taken together, the purinergic hypothesis of AP mechanism has opened new vistas to understand what happens at AP points and is expected to uncover more valuable details in future. We still do not know which layer (skin, muscles, vessels, nerve endings, etc.), which cell types (keratinocytes, melanocytes, Merkel cells, Langerhans cells, fibroblasts, myocytes, vascular endothelial cells, etc.) at the AP point are responsible for AP effects. The release of purines in relation to the 14 main meridians of the human body, assumed to be tightly connected with AP according to Traditional Chinese Medicine (TCM), is also unknown. There are many further open questions: (1) Which of the purine degrading enzymes (CD39, CD73) have the largest impact on AP?; (2) Which of the P2 receptors (P2X1, P2X4, P2X5, P2X6, P2X7, P2Y2, P2Y4, P2Y6, P2Y11, P2Y12, $\mathrm{P} 2 \mathrm{Y} 13, \mathrm{P} 2 \mathrm{Y} 14)$ are most important for AP?; and (3) Do $\mathrm{P} 2 \mathrm{X} / \mathrm{Y}$ receptors interact with other transmitter receptors in constituting AP effects? Especially the translational research from bench to bedside should be considered for AP research in the future.

\section{Important ideas to promote our knowledge on the natural scientific basis of acupuncture: Yong Tang (Chengdu, China)}

Geoff delivered three inspiring lectures on purinergic signalling and AP in the course of his life, two in Chengdu and one in Leipzig. In the winter of 2011, based on the recommendation of Geoff, Peter Illes (Leipzig University, Germany) and Yong Tang (Chengdu University of TCM, China) worked together to write a proposal to the Sino-German Center for the Promotion of Science and obtained the funding for their common project in the spring of 2012.

Financed by this project, the three co-chairs (Geoff, Peter, and Yong) (Fig. 2), organized the "1st Sino-German Symposium on Purinergic Signalling, Pain and Acupuncture" in Chengdu between October 10 and 15, 2012. Geoff, at the age of 83, flew to China with his wife Nomi at the official invitation of the Chengdu University of TCM and opened this meeting with a 1-h introductory lecture. His excellent talk, focusing on the AP purinergic hypothesis, attracted a number of senior and junior scientists and students to the auditorium. During the conference, Geoff also met a number of AP researchers and students and 
Fig. 2 Geoffrey Burnstock, Peter Illes, and Yong Tang at the 1st Sino-German Symposium on Purinergic Signalling, Pain and Acupuncture in Chengdu, 2012. Reproduced with permission from [57]

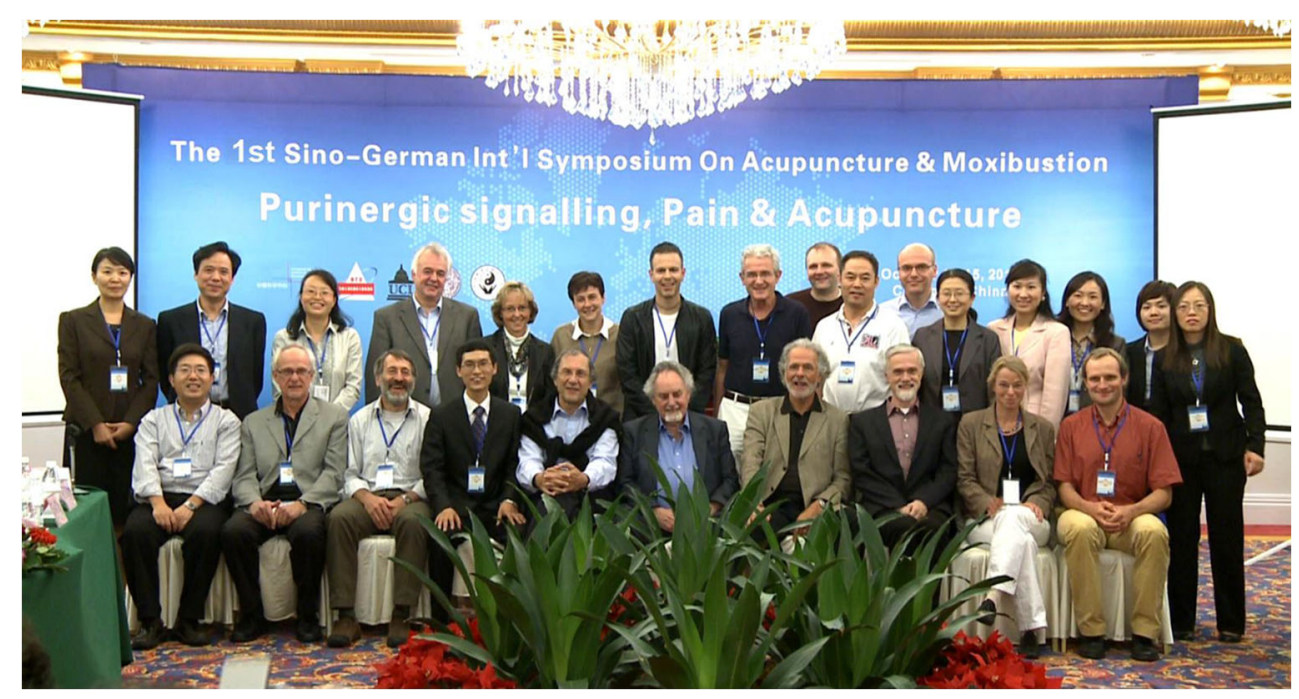

made concrete suggestions about how to perform experiments in order to test his novel hypothesis. He also initiated personal exchange activities and collaborations between the Chinese and oversea scientists to move forward the purine stories in AP.

In 2017, the "2nd Sino-German Symposium on Purinergic Signalling, Pain and Acupuncture" was held in Leipzig. Geoff, at the age of 88, came to Leipzig with his wife Nomi and again gave the opening talk on purinergic signalling and AP. His lecture greatly encouraged the participating scientists (Fig. 3) to pursue the story of purines in AP. Lectures presented by Chinese participants also inspired the prevailing confidence that purinergic signalling will explain the beneficial effects of AP in pain and inflammation, as well as in immune, vascular, respiratory, gastrointestinal, neurological, and psychological disorders.

In 2018, Geoff at an age of 89, delivered again a stimulating speech, also as an opening lecture at the "1st Chinese Purine Meeting" when the China Purine Club was founded (Fig. 4). His 1-h presentation let us witness the indomitable energy of the creator of purinergic signalling, even at this advanced age.

The purine story in acupuncture has experienced an astonishing surge in the last two centuries, from zero at the beginning, to up to over 50 publications presently, and it is still in sustained increase. Prof. Geoffrey Burnstock, the father of purinergic signalling, was appointed as Honorary Professor in the Chengdu University of TCM in 2016 and as Honorary
Fig. 3 Geoffrey Burnstock, Peter Illes, and Yong Tang at the 2nd Sino-German Symposium on Purinergic Signalling, Pain and Acupuncture in Leipzig, 2017

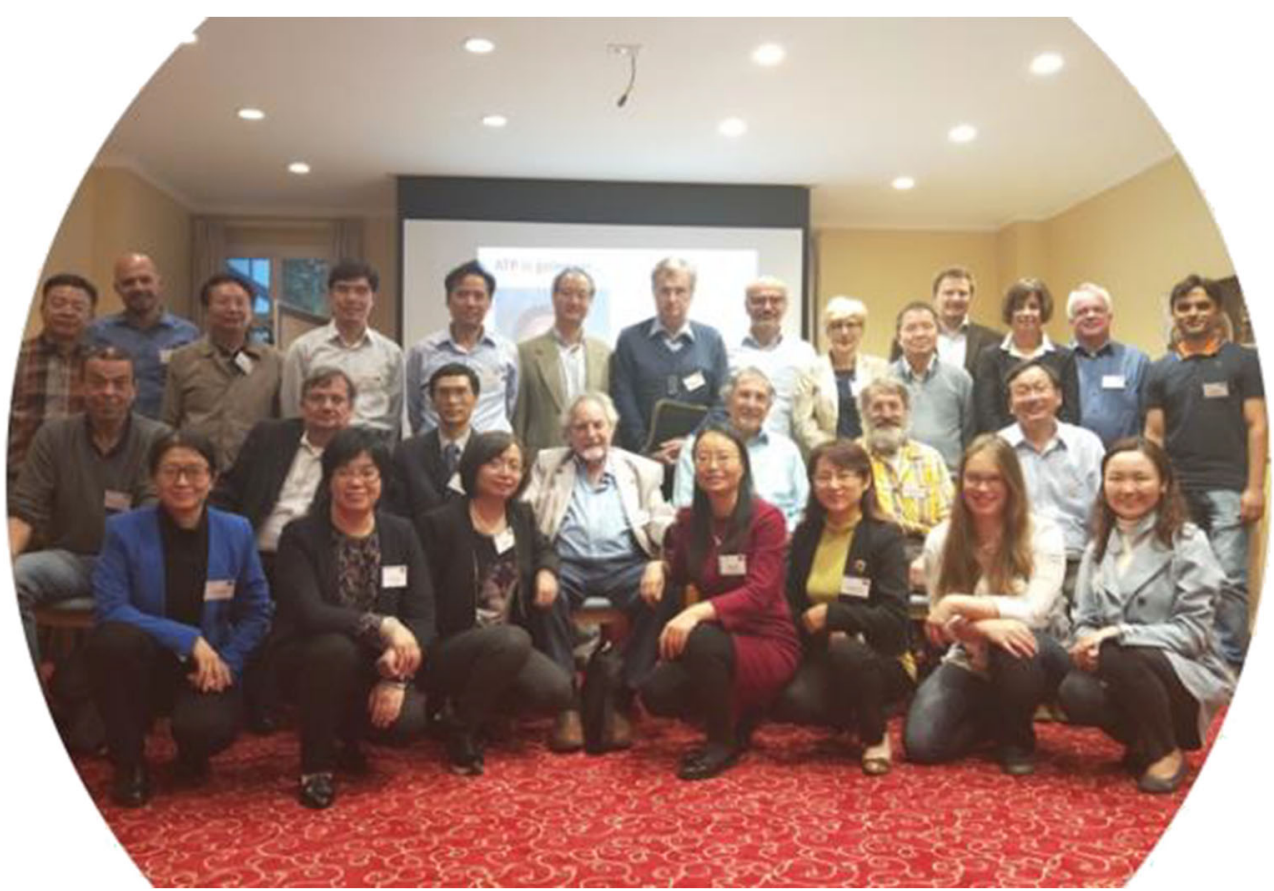




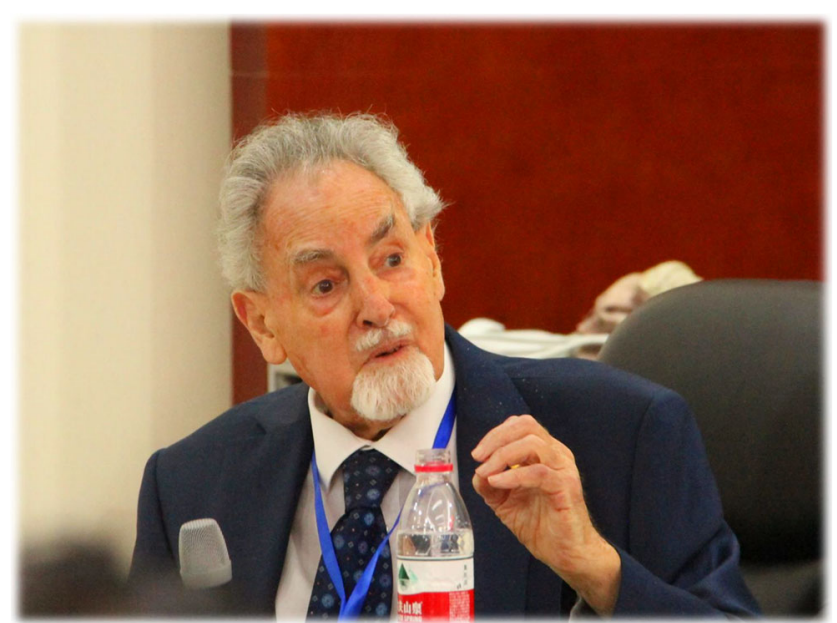

Fig. 4 The opening lecture addressed by Geoffrey Burnstock at the 1st Chinese Purine Meeting in Chengdu, 2018

President of the China Purine Club in 2018. During the two meetings in China attended by Geoff and Nomi, they visited the old city center of Chengdu, where Geoff enjoyed local sweets, and also visited the southern Yunnan Province of China, the Chendgu Panda base, and Du Fu Cottage, as well as the nearby Leshan Giant Budda (Fig. 5).

Geoff, we will miss you badly in the future.

\section{My encounters with Geoff (Peter Illes, Leipzig, Germany)}

When looking back on my encounters with Geoff, I remember seeing him the first time in 1976 in Varna, Bulgaria, at a Conference organized on Smooth Muscle Physiology. He spoke of course about purinergic transmission in the taenia coli, eloquent as always, and I was most impressed by his talk. At this time, I was a resident of my hometown, Budapest
(Hungary), where I had been working at the Department of Pharmacology of the Semmelweis University of Medicine for 10 years after graduation from Medical School. I was deeply impressed by Geoff's talk and was able to present to him my poster on sympathetic transmission in the guinea-pig vas deferens, which he criticized in a friendly, but decisive manner, and in the retrospect, quite correctly.

The second time I came into contact with him, I was working in Freiburg (Germany) where I stayed from 1981 onwards, at the Department of Pharmacology of the University, as a naturalized German citizen. In 1983, I published a review on noradrenaline as a neuroeffector transmitter in the vas deferens, and discussed at length the riddle of why $\alpha$ - and $\beta$-adrenoceptor antagonists fail to block the excitatory junction potentials known to induce mechanical contractions in this organ [58]. The current idea was that although noradrenaline is released from the sympathetic nerve terminals and acts at postsynaptic $\alpha$-adrenoceptors located at the smooth muscle, a basement membrane generates an anatomical barrier to block the free diffusion of the abovementioned antagonists to the receptor. Another hypothesis even suggested that a third type of adrenoceptor termed " $\gamma$ " mediated the noradrenaline effects. Geoff sent me a letter in which he called my attention to the purinergic hypothesis and the strong evidence that the cotransmitter ATP rather than noradrenaline itself is the neuroeffector transmitter. Soon afterwards, I became also an enthusiastic advocate of this idea and joined the purinergic community.

Subsequently, he furthered my career many times, for example by inviting me to join the Editorial Board of the newly founded journal Purinergic Signalling, or supporting the Leipzig application for a Dislocated Research Group in 2007. It was a difficult task to convince the responsible bureaucrats of the German Research Council that such an initiative made sense. Geoff was a member of the Board evaluating our application and enthusiastically supported it. In
Fig. 5 Geoffrey Burnstock visited Leshan Giant Buddha in 2012
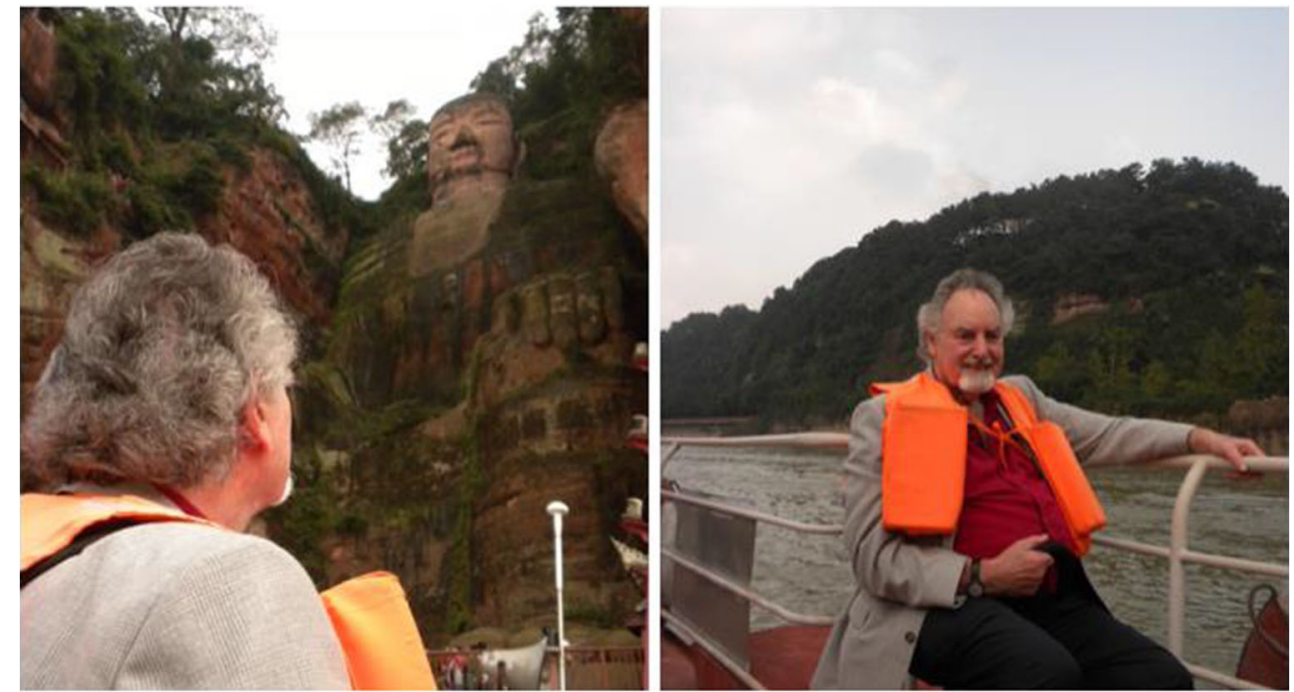
consequence, the Research Group became established and was very productive over its 6-year period of functioning [59].

I had the opportunity to meet Geoff at many International Purine Congresses and scientific events in diverse countries. Especially memorable were our encounters in Budapest on occasion of him becoming Honorary Member of the Hungarian Pharmacological Society in 2006, and in Leipzig, on occasion of the awarding of an Honorary Doctorate of our University (2011). In both cases, he was accompanied by Nomi and we spent many hours enjoying animated conversation, good food, and tasty wine.

I have co-authored nine publications with Geoff, both original reports and review articles. One of them was especially successful, becoming a "highly cited paper" according to ISI Web of Science [60]. During our accidental co-operation, I learned to admire his sharp intellect and gift to describe complicated scientific processes in understandable and concise wording.

He had probably the greatest influence on my "late" scientific career after having retired as a Chairman of the Department of Pharmacology in Leipzig, by establishing a contact with Prof. Yong Tang (Chengdu, China) [57]. Yong has given an account of our common activities in the "Important ideas to promote our knowledge on the natural scientific basis of acupuncture: Yong Tang (Chengdu, China)" section.

In conclusion, let me state that having lost Geoff, as a benevolent friend, fatherly figure, and illuminating ideal is a huge personal hardship.

Funding This article received funding from National Key R\&D Program of China (2019YFC1709101), the Project First-Class Disciplines Development of Chengdu University of Traditional Chinese Medicine (CZYHW1901) in order to build up the "International Collaborative Centre on Big Science Plan for Purine Signalling," State Administration of Foreign Experts Affairs to support the stays of P.I. in Chengdu (G20190236012), National Natural Science Foundation of China (81373735, 81873240), and Science and Technology Program of Sichuan Province, China (2019YFH0108).

\section{Compliance with ethical standards}

Conflict of interest The authors declare that they have no conflict of interest.

Ethical approval This article does not contain any studies with human participants or animals performed by any of the authors.

Open Access This article is licensed under a Creative Commons Attribution 4.0 International License, which permits use, sharing, adaptation, distribution and reproduction in any medium or format, as long as you give appropriate credit to the original author(s) and the source, provide a link to the Creative Commons licence, and indicate if changes were made. The images or other third party material in this article are included in the article's Creative Commons licence, unless indicated otherwise in a credit line to the material. If material is not included in the article's Creative Commons licence and your intended use is not permitted by statutory regulation or exceeds the permitted use, you will need to obtain permission directly from the copyright holder. To view a copy of this licence, visit http://creativecommons.org/licenses/by/4.0/.

\section{References}

1. Abbracchio MP, Jacobson KA, Müller CE, Zimmermann H (2020) Professor Dr. Geoffrey Burnstock (1929-2020). Purinergic Signal 16:137-149

2. Verkhratsky A, Zimmermann H, Abbracchio MP, Illes P, Di Virgilio F (2020) In memoriam Geoffrey Burnstock: creator of purinergic signaling. Function 1:zqaa006

3. NIH Consensus Conference (1998) Acupuncture. JAMA 280: $1518-1524$

4. Burnstock G (2009) Acupuncture: a novel hypothesis for the involvement of purinergic signalling. Med Hypotheses 73:470-472

5. Tang Y, Yin HY, Liu J, Rubini P, Illes P (2019) P2X receptors and acupuncture analgesia. Brain Res Bull 151:144-152

6. Tang Y, Yin HY, Rubini P, Illes P (2016) Acupuncture-induced analgesia: a neurobiological basis in purinergic signaling. Neuroscientist 22:563-578

7. He JR, Yu SG, Tang Y, Illes P (2020) Purinergic signaling as a basis of acupuncture-induced analgesia. Purinergic Signal. https:// doi.org/10.1007/s11302-020-09708-Z

8. Han JS (2004) Acupuncture and endorphins. Neurosci Lett 361: 258-261

9. Skrabanek P (1984) Acupuncture and endorphins. Lancet 28:220

10. Burnstock G (2011) Puncturing the myth. Purinergic signaling, not mystical energy, may explain how acupuncture works. Scientist 25: $24-25$

11. Burnstock G (2014) Purinergic signaling in acupuncture. Science 346(6216 Suppl):S23-S25

12. Takano T, Chen X, Luo F, Fujita T, Ren Z, Goldman N, Zhao Y, Markman JD, Nedergaard M (2012) Traditional acupuncture triggers a local increase in adenosine in human subjects. J Pain 13: $1215-1223$

13. Ye TS, Du ZH, Li ZH, Xie WX, Huang KT, Chen Y, Chen ZY, Hu H, Wang JL, Fang JQ (2016) Repeated electroacupuncture persistently elevates adenosine and ameliorates collagen-induced arthritis in rats. Evid Based Complement Alternat Med 2016:3632168

14. Shinbara H, Nagaoka S, Izutani Y, Okubo M, Kimura K, Mizunuma K, Sumiya E (2017) Contribution of adenosine to the increase in skeletal muscle blood flow caused by manual acupuncture in rats. Acupunct Med 35:284-288

15. Cheng LL, Wu CY, Sui MH (2012) Effects of electroacupuncture of "Weizhong" (BL40), "Sanyinjiao" (SP 6) and "Yinlingquan" (SP 9) on intravesical pressure and bladder adenosine triphosphate content in rabbits with acute urinary retention. Zhen Ci Yan Jiu 37: 291-295

16. Hu L, Wang L, Wei J, Ryszard G, Shen X, Wolfgang S (2015) Heat induces adenosine triphosphate release from mast cells in vitro: a putative mechanism for moxibustion. J Tradit Chin Med 35:323328

17. Wang JY, Li H, Zhang L, Ma CM, Wang JL, Lai XS, Zhou SF (2014) Adenosine as a probing tool for the mechanistic study of acupuncture treatment. Clin Exp Pharmacol Physiol 41:933-939

18. Huang M, Wang X, Xing B, Yang H, Sa Z, Zhang D, Yao W, Yin N, Xia Y, Ding G (2018) Critical roles of TRPV2 channels, histamine $\mathrm{H} 1$ and adenosine $\mathrm{A} 1$ receptors in the initiation of acupoint signals for acupuncture analgesia. Sci Rep 8:6523

19. Goldman N, Chen M, Fujita T, Xu Q, Peng W, Liu W, Jensen TK, Pei Y, Wang F, Han X, Chen JF, Schnermann J, Takano T, Bekar L, Tieu K, Nedergaard M (2010) Adenosine A1 receptors mediate local anti-nociceptive effects of acupuncture. Nat Neurosci 13: 883-888

20. Qu F, Cui Y, Zeng J, Zhang M, Qiu S, Huang X, Chen A (2020) Acupuncture induces adenosine in fibroblasts through energy metabolism and promotes proliferation by activating MAPK signaling pathway via adenosine 3 receptor. J Cell Physiol 235:2441-2451 
21. Dai QF, Wang YY, Liu Q, Xin JJ, Lu FY, Cui JJ, Wu SY, Zhou C, Zhao YX, Gao JH, Yu XC (2018) A potential role of adenosine a 2 $\mathrm{b}$ receptor in mediating acupuncture pretreatment induced cardioprotection via influencing intracellular calcium regulator. Zhen Ci Yan Jiu 43:576-580

22. Hou T, Xiang H, Yu L, Su W, Shu Y, Li H, Zhu H, Lin L, Hu X, Liang S, Zhang H, Li M (2019) Electroacupuncture inhibits visceral pain via adenosine receptors in mice with inflammatory bowel disease. Purinergic Signal 15:193-204

23. Zhang M, Dai Q, Liang D, Li D, Chen S, Chen S, Han K, Huang L, Wang J (2018) Involvement of adenosine A1 receptor in electroacupuncture-mediated inhibition of astrocyte activation during neuropathic pain. Arq Neuropsiquiatr 76:736-742

24. Ren W, Tu W, Jiang S, Cheng R, Du Y (2012) Electroacupuncture improves neuropathic pain: adenosine, adenosine 5 -triphosphate disodium and their receptors perhaps change simultaneously. Neural Regen Res 7:2618-2623

25. Du ZH, Zhang CW, Xie WX, Chen Y, Cong WJ, Wang ZD, Wang EP, Wu GY, Ye TS (2019) Adenosine A2A receptor mediates inhibition of synovitis and osteoclastogenesis after electroacupuncture in rats with collagen-induced arthritis. Evid Based Complement Alternat Med 2019:4617464

26. Chen ZH, Wang R, Xie J, Ren YL (2019) Mechanism of acupoint selection along meridians to improve adenosine receptor of myocardial ischemia based on acupoint specificity. Zhongguo Zhen Jiu 39:855-860

27. Lu S, Tang Y, Ding Y, Yu M, Fu S, Zhu B (2018) Effects of electroacupuncture on the expression of adenosine receptors in the heart tissue of myocardial ischemia rats. Zhongguo Zhen Jiu 38:173-179

28. Tang YX, Meng JZ, Ding YJ, Hong H, Yu ML, Jing XY, Lu SF, Zhu BM (2017) Effect of electroacupuncture on adenosine receptor expression in white adipose tissue of diet-induced obese mice. Zhen Ci Yan Jiu 42:39-44

29. Dai QF, Gao JH, Xin JJ, Liu Q, Jing XH, Yu XC (2019) The role of adenosine $\mathrm{A} 2 \mathrm{~b}$ receptor in mediating the cardioprotection of electroacupuncture pretreatment via influencing $\mathrm{Ca}^{2+}$ key regulators. Evid Based Complement Alternat Med 2019:6721286

30. Ren Y, Chen Z, Wang R, Yu Y, Li D, He Y (2020) Electroacupuncture improves myocardial ischemia injury via activation of adenosine receptors. Purinergic Signal. https://doi.org/10. 1007/s11302-020-09704-3

31. Li QH, Xie WX, Li XP, Huang KT, Du ZH, Cong WJ, Zhou LH, Ye TS, Chen JF (2015) Adenosine A2A receptors mediate antiinflammatory effects of electroacupuncture on synovitis in mice with collagen-induced arthritis. Evid Based Complement Alternat Med 2015:809560

32. Zylka MJ (2010) Needling adenosine receptors for pain relief. Nat Neurosci 13:783-784

33. Malik S, Samaniego T, Guo ZL (2019) Adenosine receptor A2a, but not A1 in the rVLM participates along with opioids in acupuncture-mediated inhibition of excitatory cardiovascular reflexes. Front Neurosci 13:1049

34. Liang DD, Wang HF, Zhang MX, Dai QX, Liu HP, Mo YC, Wang JL (2013) Local adenosine A1 receptors of baihui acupoint mediate cerebral ischemia tolerance induced by electroacupuncture. Zhonghua Yi Xue Za Zhi 93:537-540

35. Weng Z, Wu L, Lu Y, Wang L, Tan L, Dong M, Xin Y (2013) Electroacupuncture diminishes $\mathrm{P} 2 \mathrm{X} 2$ and $\mathrm{P} 2 \mathrm{X} 3$ purinergic receptor expression in dorsal root ganglia of rats with visceral hypersensitivity. Neural Regen Res 8:802-808

36. Xiang X, Wang S, Shao F, Fang J, Xu Y, Wang W, Sun H, Liu X, Du J, Fang J (2019) Electroacupuncture stimulation alleviates CFAinduced inflammatory pain via suppressing P2X3 expression. Int J Mol Sci 20:3248
37. Zhou YF, Ying XM, He XF, Shou SY, Wei JJ, Tai ZX, Shao XM, Liang Y, Fang F, Fang JQ, Jiang YL (2018) Suppressing PKCdependent membrane $\mathrm{P} 2 \mathrm{X} 3$ receptor upregulation in dorsal root ganglia mediated electroacupuncture analgesia in rat painful diabetic neuropathy. Purinergic Signal 14:359-369

38. Fang JQ, Du JY, Fang JF, Xiao T, Le XQ, Pan NF, Yu J, Liu BY (2018) Parameter-specific analgesic effects of electroacupuncture mediated by degree of regulation TRPV1 and P2X3 in inflammatory pain in rats. Life Sci 200:69-80

39. Weng ZJ, Wu LY, Zhou CL, Dou CZ, Shi Y, Liu HR, Wu HG (2015) Effect of electroacupuncture on P2X3 receptor regulation in the peripheral and central nervous systems of rats with visceral pain caused by irritable bowel syndrome. Purinergic Signal 11:321-329

40. Chen L, Leng C, Gong X, Ma B, Ru Q, Xiong Q, Zhou M, Tian X, Yue K, Li C, Wu Y (2019) 2Hz EA reduces heroin withdrawalinduced hyperalgesia and heroin relapse by downregulating P2X3 receptors in DRG neurons. Biomed Res Int 2019:1873859

41. Liang Y, Gu Y, Shi R, Li G, Chen Y, Huang LM (2019) Electroacupuncture downregulates $\mathrm{P} 2 \mathrm{X} 3$ receptor expression in dorsal root ganglia of the spinal nerve-ligated rat. Mol Pain 15: 1744806919847810

42. Wang WS, Tu WZ, Cheng RD, He R, Ruan LH, Zhang L, Gong YS, Fan XF, Hu J, Cheng B, Lai YP, Zou EM, Jiang SH (2014) Electroacupuncture and A-317491 depress thetransmission of pain on primary afferent mediated by the $\mathrm{P} 2 \mathrm{X} 3$ receptor in rats with chronic neuropathic pain states. J Neurosci Res 92:1703-1713

43. Yu J, Zhao C, Luo X (2013) The effects of electroacupuncture on the extracellular signal-regulated kinase 1/2/P2X3 signal pathway in the spinal cord of rats with chronic constriction injury. Anesth Analg 116:239-246

44. Xiao Z, Ou S, He WJ, Zhao YD, Liu XH, Ruan HZ (2010) Role of midbrain periaqueductal gray $\mathrm{P} 2 \mathrm{X} 3$ receptors in electroacupuncture-mediated endogenous pain modulatory systems. Brain Res 1330:31-44

45. Cheng RD, Tu WZ, Wang WS, Zou EM, Cao F, Cheng B, Wang JZ, Jiang YX, Jiang SH (2013) Effect of electroacupuncture on the pathomorphology of the sciatic nerve and the sensitization of P2X4 receptors in the dorsal root ganglion in rats with chronic constrictive injury. Chin J Integr Med 19:374-379

46. Tu WZ, Cheng RD, Cheng B, Lu J, Cao F, Lin HY, Jiang YX, Wang JZ, Chen H, Jiang SH (2012) Analgesic effect of electroacupuncture on chronic neuropathic pain mediated by $\mathrm{P} 2 \mathrm{X} 3$ receptors in rat dorsal root ganglion neurons. Neurochem Int 60:379-386

47. Guo X, Chen J, Lu Y, Wu L, Weng Z, Yang L, Xin Y, Lin X, Liang Y, Fang J (2013) Electroacupuncture at He-Mu points reduces $\mathrm{P} 2 \mathrm{X} 4$ receptor expression in visceral hypersensitivity. Neural Regen Res 8:2069-2077

48. Chen XM, Xu J, Song JG, Zheng BJ, Wang XR (2015) Electroacupuncture inhibits excessive interferon- evoked upregulation of $\mathrm{P} 2 \mathrm{X} 4$ receptor in spinal microglia in a $\mathrm{CCI}$ rat model for neuropathic pain. Br J Anaesth 114:150-157

49. Gao YH, Li CW, Wang JY, Tan LH, Duanmu CL, Jing XH, Chang XR, Liu JL (2017) Effect of electroacupuncture on the cervicospinal P2X7 receptor/fractalkine/CX3CR1 signaling pathway in a rat neck-incision pain model. Purinergic Signal 13:215225

50. Xu J, Chen XM, Zheng BJ, Wang XR (2016) Electroacupuncture relieves nerve injury-induced pain hypersensitivity via the inhibition of spinal P2X7 receptor-positive microglia. Anesth Analg 122: 882-892

51. Liu S, Shi Q, Zhu Q, Zou T, Li G, Huang A, Wu B, Peng L, Song M, Wu Q, Xie Q, Lin W, Xie W, Wen S, Zhang Z, Lv Q, Zou L, Zhang X, Ying M, Li G, Liang S (2015) P2X7 receptor of rat dorsal root ganglia is involved in the effect of moxibustion on visceral hyperalgesia. Purinergic Signal 11:161-169 
52. Shen D, Shen X, Schwarz W, Grygorczyk R, Wang L (2020) P2Y13 and P2X7 receptors modulate mechanically induced adenosine triphosphate release from mast cells. Exp Dermatol 29:499-508

53. Liao HY, Hsieh CL, Huang CP, Lin YW (2017) Electroacupuncture attenuates CFA-induced inflammatory pain by suppressing Nav1.8 through S100B, TRPV1, opioid, and adenosine pathways in mice. Sci Rep 7:42531

54. Liao HY, Hsieh CL, Huang CP, Lin YW (2017) Electroacupuncture attenuates induction of inflammatory pain by regulating opioid and adenosine pathways in mice. Sci Rep 7:15679

55. Li P, Ge M, Lin D, Yang L (2019) Functionalized acupuncture needle as a SERS-active platform for rapid and sensitive determination of adenosine triphosphate. Anal Bioanal Chem 411(22): 5669-5679

56. Hurt JK, Zylka MJ (2012) PAPupuncture has localized and longlasting antinociceptive effects in mouse models of acute and chronic pain. Mol Pain 8:28
57. Tang Y, Yin HY, Illes P, Burnstock G, Chen JF (2019) From the Sino-German collaboration on purines to the Chinese Purine Club. Purinergic Signal 15:387-389

58. Illes P (1983) Electrophysiology of noradrenaline release from smooth muscle organs. Trends Pharmacol Sci 4:335-338

59. Schöneberg T, Illes P, Burnstock G (2010) The German Research Unit "Neuronal and glial P2 receptors; molecular basis and functional significance". Purinergic Signal 6:285-287

60. Burnstock G, Krügel U, Abbracchio MP, Illes P (2011) Purinergic signalling: from normal behaviour to pathological brain function. Prog Neurobiol 95:229-274

Publisher's note Springer Nature remains neutral with regard to jurisdictional claims in published maps and institutional affiliations. 